\title{
Characterization of genome-reduced Bacillus subtilis strains and their application for the production of guanosine and thymidine
}

\author{
Yang Li ${ }^{1,4}$, Xujun Zhu' ${ }^{1}$, Xueyu Zhang ${ }^{1,3}$, Jing Fu' ${ }^{1}$, Zhiwen Wang ${ }^{1}$, Tao Chen ${ }^{1,2^{*}}$ and Xueming Zhao
}

\begin{abstract}
Background: Genome streamlining has emerged as an effective strategy to boost the production efficiency of bio-based products. Many efforts have been made to construct desirable chassis cells by reducing the genome size of microbes. It has been reported that the genome-reduced Bacillus subtilis strain MBG874 showed clear advantages for the production of several heterologous enzymes including alkaline cellulase and protease. In addition to enzymes, B. subtilis is also used for the production of chemicals. To our best knowledge, it is still unknown whether genome reduction could be used to optimize the production of chemicals such as nucleoside products.

Results: In this study, we constructed a series of genome-reduced strains by deleting non-essential regions in the chromosome of $B$. subtilis 168. These strains with genome reductions ranging in size from 581.9 to $814.4 \mathrm{~kb}$ displayed markedly decreased growth rates, sporulation ratios, transformation efficiencies and maintenance coefficients, as well as increased cell yields. We re-engineered the genome-reduced strains to produce guanosine and thymidine, respectively. The strain BSK814G2, in which purA was knocked out, and prs, purF and guaB were co-overexpressed, produced $115.2 \mathrm{mg} / \mathrm{L}$ of guanosine, which was 4.4-fold higher compared to the control strain constructed by introducing the same gene modifications into the parental strain. We also constructed a thymidine producer by deleting the $t d k$ gene and overexpressing the prs, ushA, thyA, dut, and ndk genes from Escherichia coli in strain BSK756, and the resulting strain BSK756T3 accumulated $151.2 \mathrm{mg} / \mathrm{L}$ thymidine, showing a 5.2-fold increase compared to the corresponding control strain.
\end{abstract}

Conclusions: Genome-scale genetic manipulation has a variety of effects on the physiological characteristics and cell metabolism of B. subtilis. By introducing specific gene modifications related to guanosine and thymidine accumulation, respectively, we demonstrated that genome-reduced strains had greatly improved properties compared to the wild-type strain as chassis cells for the production of these two products. These strains also have great potential for the production of other nucleosides and similar derived chemicals.

Keywords: Bacillus subtilis, Genome reduction, Chassis cell, Guanosine, Thymidine, Nucleosides

\section{Background}

In recent years, there has been considerable interest in biotechnology and synthetic biology research concerning the design and construction of an optimal chassis

\footnotetext{
${ }^{*}$ Correspondence: chentao@tju.edu.cn

${ }^{1}$ Key Laboratory of Systems Bioengineering (Ministry of Education), SynBio Research Platform, Collaborative Innovation Center of Chemical Science and Engineering (Tianjin), School of Chemical Engineering and Technology, Tianjin University, Tianjin 300072, China

Full list of author information is available at the end of the article
}

cell [1]. Genome streamlining is an effective strategy for obtaining promising and robust host cells [2]. Genome reduction is a universal phenomenon in symbiotic bacteria and certain other bacteria that inhabit highly specialized habitats [3]. Inspired by these natural evolutionary events, researchers proposed that an ideal chassis cell can be generated by genome engineering and accelerated evolution [4]. Bacterial genomes show great diversity in size and composition, and this diversity is the result of millions of years of horizontal gene transfer and other 
complex evolutionary events $[5,6]$. It is expected that the removal of a number of non-essential regions from a bacterial chromosome will facilitate the optimization of metabolic pathways and energy utilization by enhancing the predictability of genetic engineering, which can improve overall metabolic performance [7]. Based on this vision, studies have been conducted to streamline genomes and build minimized cell factories for the production of a variety of drugs, biofuels and other bio-based chemicals [8-10].

Previous studies revealed that genome reduction resulted in beneficial traits such as genotypic stability and phenotypic validity. For example, the Escherichia coli strain MDS42, that lacks $14.3 \%$ of the parent strain's genome, displayed high electroporation efficiency and stable propagation of plasmids [11]. The mutant strain was further engineered and showed an $83 \%$ increase of threonine production compared to the parental strain engineered with the same modifications [10]. L-threonine production was increased 2.4-fold when the corresponding gene modifications were introduced into $E$. coli strain MGF-01 that has a $22 \%$ genome reduction [12]. For deletion mutants E. coli DGF-327 and DGF-298, an improvement of growth fitness was associated with the down-regulation of genes encoding chaperones and proteases [13]. A prophage-free Corynebacterium glutamicum with a $6 \%$ reduced genome showed improved growth and fitness under SOS-response-inducing conditions, significantly increased transformation efficiency, as well as $30 \%$ higher production of a heterologous model protein [14]. A genome-reduced Streptomyces avermitilis strain was also demonstrated to be highly suitable and effective for the heterologous production of antibiotics [8]. Additionally, a Pseudomonas putida strain with a reduced genome size was reported to achieve an increased biomass yield and enhanced heterologous gene expression [15].

However, deletion of some of the chosen non-essential regions (genes) also led to perturbations in the physiological characteristics of the strains, which led to a reduced growth rate and unstable phenotype. For Bacillus subtilis MG1M, with a genome reduction of $0.99 \mathrm{Mb}$, this meant a reduction in its growth rate, an aberrant cell morphology and unstable productivity of recombinant proteins during successive culture passages [16]. It was also reported that genome reduction decreased the carrying capacity of $E$. coli for foreign genes as well as its growth fitness [17]. Most recently, Unthan et al. investigated the impact of reductions encompassing 41 regions in the genome of C. glutamicum on the strain's biological fitness. The single deletions of 10 individual regions resulted in impaired growth rates, and 26 regions were unnecessary for maintaining biological fitness at wildtype level [18].

Bacillus subtilis and related bacteria are widely used as hosts for industrial production of enzymes and other biobased chemicals [19]. Some efforts have been made to streamline the genome of $B$. subtilis and improve its performance and suitability as a chassis cell. The $B$. subtilis $\Delta 6$ strain, which has a $7.7 \%$ genome reduction, showed normal competence and sporulation phenotype, but exhibited a change of motility [20]. The strain MGB874, with about $20.7 \%$ genome reduction, showed a reduced growth rate and aberrant gene transcription patterns. Moreover, the strain showed clearly improved characteristics compared to the wild-type concerning the production of alkaline cellulase and alkaline protease, displaying both a higher cell yield and a higher specific productivity [21, 22]. However, the production of the alkaline $\alpha$-amylase AmyK38 was significantly decreased in strain MGB874 [23]. After introduction of an exogenous alkaline cellulase gene, the newly constructed cellulaseproducing MGB874 exhibited a significantly increased flux in the pentose phosphate pathway, compared to an equivalently modified cellulase-producing derivative of the wild-type strain [24].

Apart from enzymes, B. subtilis has also been used widely for the production of small-molecule chemicals such as nucleosides [25], riboflavin [26], D-ribose [27], 2,3-butanediol [28] and acetoin [29]. Compared to other kinds of chemicals, the accumulation of nucleosides is more likely to be positively affected by genome reduction, since a part of the metabolic resources which would have been used for genome replication becomes available. Thus, we focused on the potential of genome reduction in B. subtilis for improving the production of guanosine and thymidine. We constructed genome-reduced strains of $B$. subtilis by reducing the genome size by up to $814.4 \mathrm{~kb}$, and investigated the impacts of genome reduction on cell growth features, spore formation, transformation efficiency and maintenance energy requirements. Subsequently, by introducing genetic modifications which induce guanosine and thymidine accumulation, we demonstrated the great advantages and increased effectiveness of genome-reduced strains as chassis cells for the production of nucleoside products.

\section{Results and discussion}

\section{Construction of genome-reduced B. subtilis strains}

There are latent prophages, gene clusters related to antibiotic synthesis, and other regions scattered across the genome of $B$. subtilis 168 , which do not contribute to performance in a typical industrial strain [20, 21, 30]. In order to avoid serious deviations of the terminus of replication from the original position due to concomitant 
deletion of multiple fragments, we carried out deletions of the non-essential regions in a pre-designed order (see Additional file 1: Figure S1). We sequentially deleted all known prophage regions (pro1, 2, 3, 4, 5, 6, sp $\beta$, skin and PBSX), antibiotic production operons (pps, $p k s$ ) as well as a number of additional, miscellaneous non-essential regions (ycxB-sipU, yisB-yitD, pdp-rocR, yrkS-yraK, yybP-yyaJ, ydeK-ydjC, lytH -yurT, sboA-ywhH). The sizes of deleted regions added up to a total $814.4 \mathrm{~kb}$. Although the regions chosen were somewhat similar to previous work reported by Morimoto et al. [21], a number of specific genes and the lengths of target regions deleted in this study were different (Additional file 1: Table S1). For example, some genes involved in spore development such as spoIVCB, spoIIIC, spoOA and sigE were not deleted in our study. On the other hand, we also eliminated some of the non-essential genes, which were not knocked out in the Morimoto et al. study, such as $y d h U$, yitD, sspG and $y u r S$. Taken as a whole, we deleted a smaller number of non-essential regions (see Additional file 1: Table S1) than what the above-mentioned study reported [21].

Large-scale genome deletions are likely to affect cell growth, cell division, spore differentiation and substrate as well as energy utilization. However, owing to our limited understanding of genes still lacking annotation, as well as complex interactions of known genes, the effects of genome reduction on cell physiology are difficult to predict and have to be tested experimentally. Thus, in order to assess the impact of genome reduction on physiological characteristics and phenotypes, the strains BSK582, BSK665, BSK756, and BSK814 were selected for further study.

\section{Cell growth and substrate consumption}

The growth curves of selected strains cultivated in M9 medium are shown in Additional file 1: Figure S2. Compared with the parental strain BSF1, the specific rates of cell growth and glucose consumption of the genomereduced strains decreased gradually along with successively larger genome reductions. For strain BSK814, the maximal specific growth rate was only $0.41 \pm 0.02 \mathrm{~h}^{-1}$ which constituted a decrease of $24 \%$ compared to the parental strain (Table 1). The glucose consumption rate was $4.87 \pm 0.25 \mathrm{mmol} \mathrm{g}(\mathrm{cdw})^{-1} \mathrm{~h}^{-1}$ which amounts to a decrease of about $25.6 \%$. The specific growth rate of BSK814 was almost the same as that of strain MGB874, the generation time of which was reported to be $100 \mathrm{~min}$ when the strain was cultured in Spizizen's minimal medium [21]. Because many genes were deleted simultaneously as part of larger genome fragments, it is difficult to pinpoint individual genes that are most closely associated with the observed reduced growth rates. The results indicated that the successive deletion of additional genomic regions had a cumulative negative effect on cell growth and substrate consumption rate.

However, the $\mathrm{OD}_{600}$ of these strains exhibited an opposite trend. All the genome-reduced strains reached a higher $\mathrm{OD}_{600}$ than the parental strain at the plateau stage of growth. One possibility is that changes in cell morphology might influence the $\mathrm{OD}_{600}$ measurements. However, based on microscopic observation (see Additional file 1: Figure S3), the cell size and shape of the strains in stationary phase did not exhibit obvious changes compared to the parental strain. Thus, the enhanced cell $\mathrm{OD}_{600} \mathrm{can}$ be attributed to changes in cell physiology. The cell dry weigh (cdw) of strain BSK814 reached $2.2 \mathrm{~g} / \mathrm{L}$, which was $37 \%$ higher than that of the parental strain. However, no obvious difference between the CDW of genomereduced strains and the parental strain was observed when they were cultured in LB medium (data not shown). This observation was not consistent with results obtained in the study by Morimoto et al., which showed that the biomass values obtained with the genome reduced strain MGB874 and that of the wild type strain 168 were similar to each other in both LB and Spizizen's minimal medium [21]. Due to lower glucose utilization rates and higher biomass, the biomass yields of the genome reduced strains also gradually increased with the size of genome reduction (Table 1). This observation might be related to the removal of genes encoding lysozymes such as $\mathrm{CwlC}$

Table 1 Comparison of growth-related data of genome-reduced strains and the parental strain under aerobic conditions

\begin{tabular}{llllrr}
\hline Strains & BSF1 & BSK582 & BSK665 & BSK756 & BSK814 \\
\hline Specific growth rate $\left(\mathrm{h}^{-1}\right)^{\mathrm{a}}$ & $0.54 \pm 0.03$ & $0.48 \pm 0.03$ & $0.43 \pm 0.02$ & $0.42 \pm 0.02$ & $0.41 \pm 0.02$ \\
CDW $\left(\mathrm{g} \mathrm{L}^{-1}\right)^{\mathrm{b}}$ & $1.62 \pm 0.02$ & $1.64 \pm 0.01$ & $1.80 \pm 0.03$ & $2.17 \pm 0.02$ & $2.20 \pm 0.03$ \\
Specific glucose uptake rate $\left(\mathrm{mmol} \mathrm{g}^{-1} \mathrm{cdw} \mathrm{h} \mathrm{H}^{-1}\right)$ & $6.55 \pm 0.32$ & $6.20 \pm 0.26$ & $5.30 \pm 0.50$ & $5.05 \pm 0.31$ & $4.87 \pm 0.25$ \\
Glucose consumption $\left(\mathrm{g} \mathrm{L}^{-1}\right)$ & $6.56 \pm 0.12$ & $6.19 \pm 0.10$ & $6.77 \pm 0.03$ & $6.44 \pm 0.10$ & $6.38 \pm 0.16$ \\
Biomass yield (g/g glucose) & $0.26 \pm 0.01$ & $0.28 \pm 0.01$ & $0.29 \pm 0.02$ & $0.35 \pm 0.01$ & $0.36 \pm 0.01$ \\
\hline
\end{tabular}

Standard deviations were calculated from three biological replicates

a Batch cultures were performed in $100 \mathrm{ml} \mathrm{M9}$ medium with $1 \%(\mathrm{w} / \mathrm{v})$ glucose as described in method section

b $\mathrm{CDW}$ is the final cell dry weight. At end of fermentation, cells were harvested and dried at $80^{\circ} \mathrm{C}$ to a constant weight. Cell dry weight was determined by weighting the dried cells 
and LytC, both of which play an important role in phage infection, cell division and differentiation [31, 32]. It was thus interesting to determine if there are any differences in cell autolysis between the genome-reduced strains and the parental strain.

\section{Analysis of cell autolysis behaviour}

To investigate the effect of genome reduction on cell autolysis, we performed a cell lysis assay. As shown in Fig. 1a, all genome-reduced strains showed lower cell autolysis ratios compared to the parent strain BSF1. It has been reported that the deletion of the prophage and the lytic enzyme encoding gene $s k f A$, which is located in the pro1 region, contributed to a decrease of cell lysis [33]. As an illustration, nearly 69 and $66 \%$ of the BSK756 and BSK814 cells autolysed within $4 \mathrm{~h}$, respectively, while $94 \%$ of BSF1 cells autolysed within the same timeframe. There was also a significant difference between the autolysis ratios of BSK582 and BSK756 (83 vs $69 \%$ ). This might be caused by the deletion of regions such as PBSX and skin in BSK756. It was reported that deletion of xpf, which is located in the PBSX region, could also reduce the autolysis ratio [33]. On the other hand, the strain BSK814 showed an autolysis ratio and CDW similar to BSK756 (Fig. 1a; Table 1, respectively), which suggested that there were no additional active genes encoding potential autolytic lysozymes in the three deleted fragments, pro4, lyt $H-y u r T$ and $s b o A-y w h H$.

\section{Spore germination}

Endospore development and germination are basic physiological characteristics of the Bacillus genus, and the process of sporulation can be initiated under conditions of nutrient limitation. To assess the impact of genome streamlining on spore development, we examined the sporulation ratios of the genome-reduced mutant strains. The sporulation ratio of strain BSK582 was nearly unchanged compared to the parental strain. However, as the genome reduction size increased stepwise from 581.9 to $814.4 \mathrm{~kb}$, the corresponding sporulation ratios did exhibit a slight declining trend (from 33.5 to $26 \%$, Fig. 1b), although it was not statistically significant. This result can be attributed to the deletion of genes related to endospore development, including $\operatorname{cge} A$, cgeE, $\cot P$, rapF, gerk $A$, gerPA and gerPB. The genes cgeA and cgeE are involved in the maturation of the outermost spore layer, whereas $\cot P$ encodes a spore-coat protein. It was deduced that a deletion of these genes could damage or inhibit the sporulation process [34]. In addition, deletion of genes gerk $A, \operatorname{ger} P A$ and $\operatorname{ger} P B$ also led to changes in the structure and composition of the endospores, which reduced their heat resistance [35, 36]. Morimoto et al. reported that the strain MGB874 did not form spores because some key
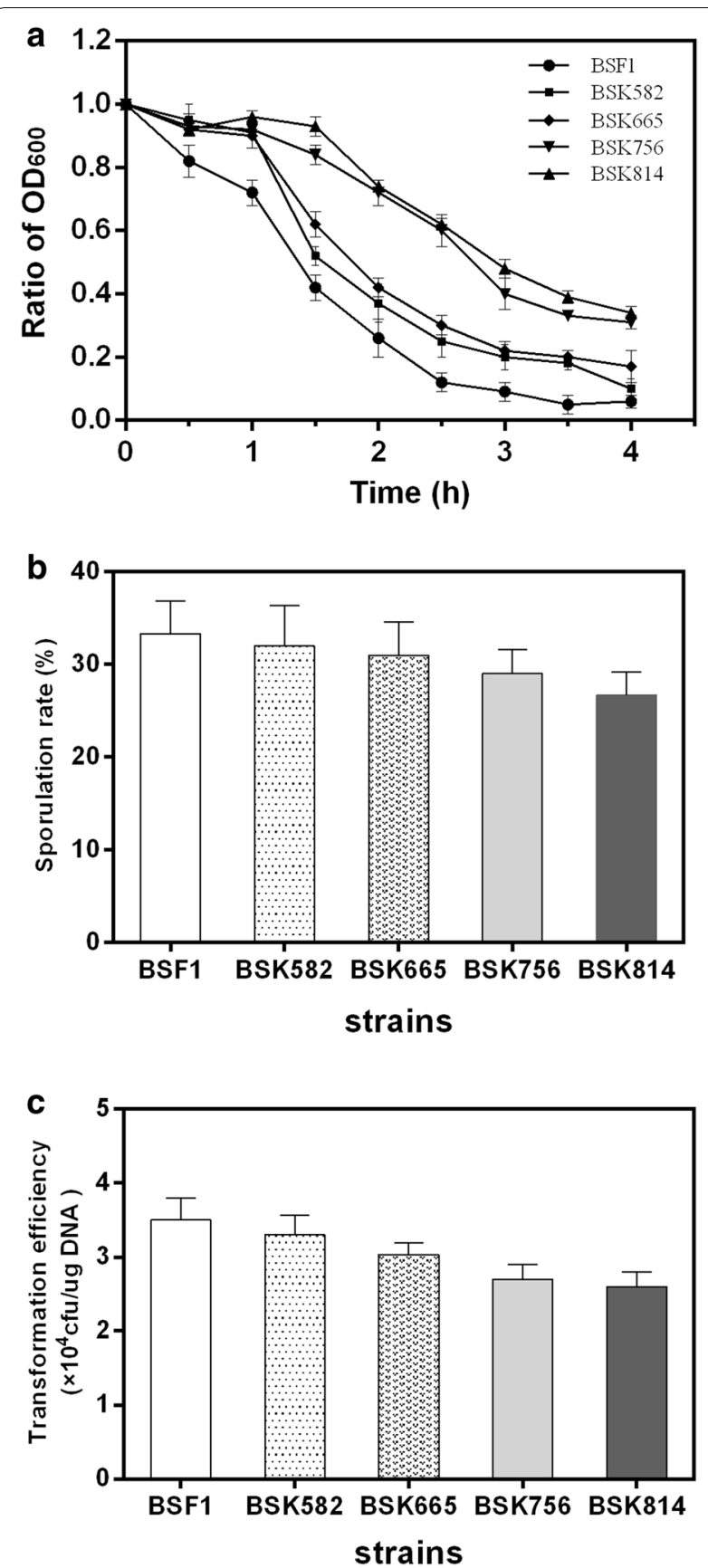

Fig. 1 Cell autolysis, sporulation ratios and transformation efficiencies of genome-reduced strains and their parental strain. a Cell autolysis assay. Autolysis was represented by the ratio of the $\mathrm{OD}_{600}$ at the indicated time-points to the corresponding initial culture $\mathrm{OD}_{600}$. b Sporulation ratios. c Transformation efficiencies. All experiments were performed in triplicate

sporulation genes were deleted, including spoIVCB and spoIIIC [21]. However, we did not remove genes spoIVCB, spoIIIC, spoOA or sigE in this study, so the sporulation 
characteristics of our genome-reduced strains were quite different from those of strain MGB874.

\section{Transformation efficiency}

As ideal chassis cells, genome-reduced strains should maintain a high transformation efficiency to facilitate further genetic modifications. In order to understand the impact of genome reduction on transformation, we measured the transformation efficiencies of the four genome-reduced strains. As shown in Fig. 1c, the transformation efficiency gradually decreased as the genome reductions increased in size. The strain BSK814 exhibited a transformation efficiency of $2.8 \times 10^{4}$ transformants per $\mu \mathrm{g}$ of plasmid DNA, which constitutes a decrease of $22 \%$ compared to the parental strain. It has been reported that the transformation frequency of $B$. subtilis $\Delta 6$ was similar to that of the parental strain [20]. We also observed that the transformation efficiencies of the strains with genome reduction sizes of less than $581.9 \mathrm{~kb}$ were on par with the parental strain (data not shown). The decreased transformation efficiency might be attributed to deletion of genes involved in competence development. However, we did not find any genes which are known to be directly associated with cell competence in the deleted regions. Natural competence of $B$. subtilis can be induced when cells undergo starvation or environmental stress, which is controlled by the quorum sensing mechanism [37]. As for the genomereduced strains, changes in physiological features and overall organization of the genome might affect the development of cell competence indirectly. In the study by Morimoto et al., it was found that the expression of comK and $\operatorname{deg} U$, which are involved in two-component signal transduction, together with a number of competence genes activated directly or indirectly by ComK, was induced earlier in MGB874 than the wild type strain, which resulted in earlier competence development. However, the impact of this change in competence development on the transformation efficiency of MGB874 was not mentioned in the report [21]. While the highest transformation efficiency for the parental strain BSF1 was obtained after $90 \mathrm{~min}$ of cultivation in SM2 medium, as reported by Vojcic [38], we observed slower growth in SM2 medium for BSK756 and BSK814, and the optimal transformation efficiencies were obtained when the cultivation time was 2.5 and $3.5 \mathrm{~h}$, respectively. Transformation efficiency is a complex feature that is affected by many factors such as cell status, growth phase, nutrient availability, DNA uptake mechanisms, concentration and configuration of donor DNA and so on [39]. Notwithstanding these complex factors influencing transformation efficiency, our results indicate that the decreased transformation efficiency of the genome-reduced strains may be mainly a result of the change in growth phase due to their slower growth rates in SM2 medium.

\section{Maintenance coefficients}

The maintenance energy coefficient is a physiological parameter that reflects the energy required for maintaining cellular homeostasis [40]. Consequently, a low maintenance energy metabolism is generally an important selection criterion for an appropriate chassis organism in order to reduce non-productive substrate consumption during the bioprocess [1, 41]. To assess whether large-scale genome reduction has a significant effect on maintenance metabolism, we determined the substrate maintenance coefficients of the genome-reduced strains in glucose-limited chemostat cultures. As shown in Fig. 2, the substrate maintenance coefficients showed a decreasing trend with increased size of genome reductions. The control strain (B. subtilis $168 \Delta$ upp::neo) had the highest maintenance coefficient of $0.43 \mathrm{mmol} \mathrm{g}(\mathrm{cdw})^{-1} \mathrm{~h}^{-1}$. This value is a bit higher than that of the wild-type strain 168 , which was reported to be $0.39 \mathrm{mmol} \mathrm{g}(\mathrm{cdw})^{-1} \mathrm{~h}^{-1}$ [42]. The difference might be caused by the changed genotype (interruption of upp gene and expression of the marker gene, neo), as well as the different minimal media and culture conditions employed in the two studies. The strain BSK814, which has the largest deletion size of $814.4 \mathrm{~kb}$, had the lowest maintenance coefficient of $0.31 \mathrm{mmol} \mathrm{g}(\mathrm{cdw})^{-1} \mathrm{~h}^{-1}$, which constitutes a decrease of $28 \%$ compared to the control strain. Tännler et al. reported that a knockout of the gene sigE resulted in an obvious decrease in substrate maintenance coefficient [42]. However, sigE was not disrupted in our study, so the significant decrease in maintenance coefficient may be mainly attributed to the large-scale genome deletion itself. Recently, it has been reported that genomereduced Pseudomonas putida strains also had lower maintenance demands and maintained a higher level of intracellular ATP than the wild-type strain under fast growth conditions [15]. Considering that the deletion of nonessential genes can make cells spend less energy and building blocks on cellular processes not associated with growth, a lower maintenance energy metabolism might be a common feature of genome-reduced strains. What's more, the maximum biomass yields of all the genomereduced strains were almost the same as that of control strain under continuous cultivation, and the value (about $0.46 \mathrm{~g} \mathrm{cdw} / \mathrm{g}$ glucose) was much higher than those measured in batch cultures (Table 1). 

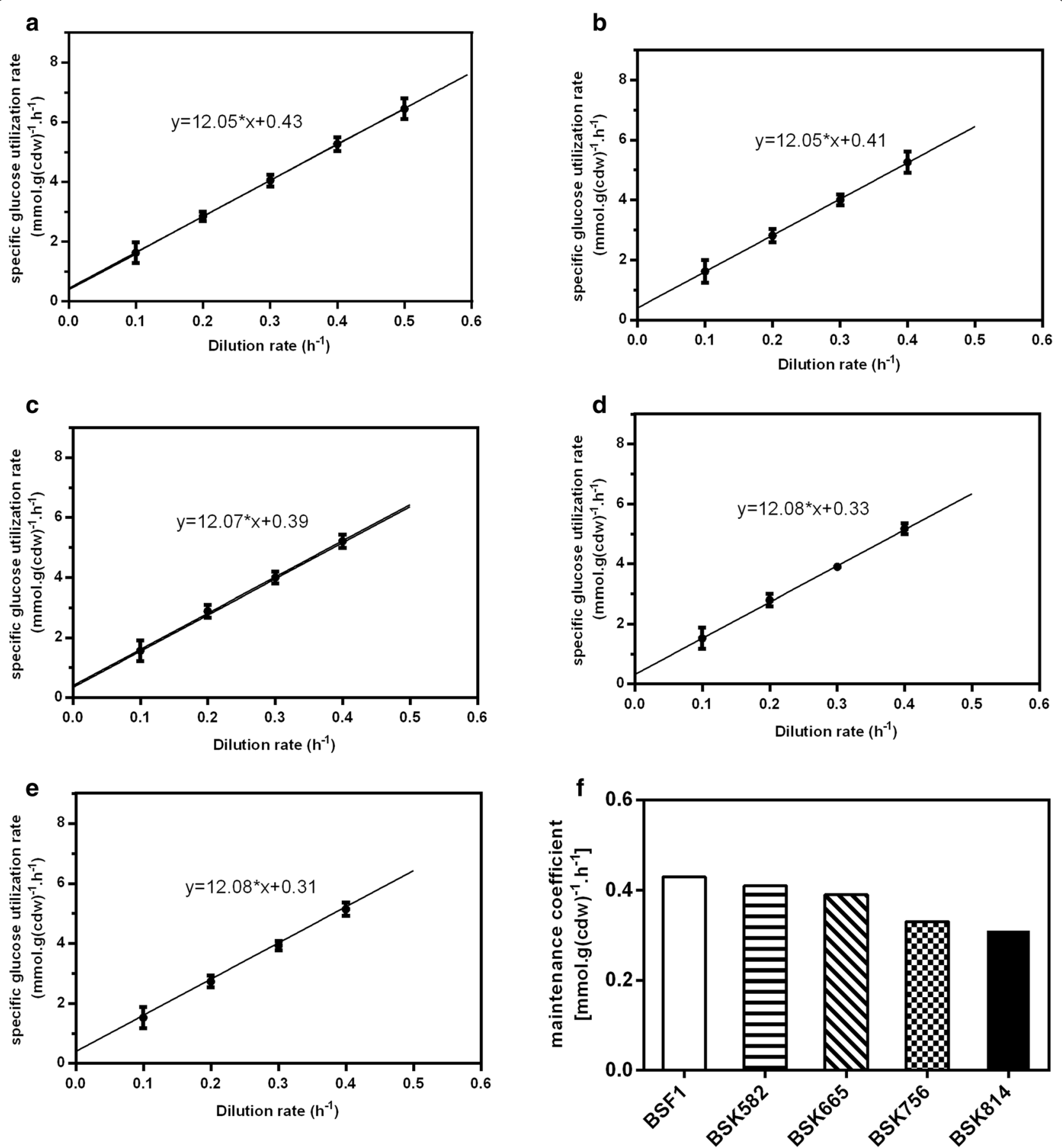

Fig. 2 Specific glucose consumption rate as a function of dilution rate in glucose-limited chemostat cultures of the indicated strains. a The control strain BSF1. b BSK582. c BSK665. d BSK756. e BSK814. f Maintenance coefficient

Application of genome-reduced strains as chassis for guanosine and thymidine production

Guanosine is an important commercial additive used in the medicine and food industries, and thymidine is a commercially useful precursor in the chemical synthesis of various antiviral drugs [43]. Both nucleosides are precursors in the synthesis of nucleic acids. In order to explore if genome-reduced strains were better suited for the production these products, we constructed guanosine 
and thymidine producers by using these strains as chassis cells.

\section{Engineering genome-reduced strains as chassis for guanosine production}

The strains BSK756 and BSK814, together with BSF1 as control, were engineered to produce guanosine. The corresponding genetic modification strategy is shown in Fig. 3. Firstly, we deleted purA to redirect carbon flux into the guanosine synthesis branch at the IMP node. The resulting stains BSF1G1, BSK756G1 and BSK814G1 were all auxotrophic for adenine, and produced 10.9, 29.5 and $32.2 \mathrm{mg} / \mathrm{L}$ of guanosine, respectively (Fig. 4a). Compared with the strain BSF1G1, the guanosine yields of BSK756G1 and BSK814G1 increased 2.7 and 2.9fold, respectively (Fig. 4b). To further increase the flux from ribose-5-phosphate to GMP, we overexpressed the prs, purF and guaB genes by placing them on a plasmid under the control of the strong $\mathrm{P}_{43}$ promoter. To achieve this, the strains BSF1G1, BSK756G1 and BSK814G1 were transformed with the triple gene overexpression plasmid pHP13-ppg, which yielded the strains BSF1G2, BSK756G2 and BSK814G2. BSK756G2 and BSK814G2 produced 104.2 and $115.2 \mathrm{mg} / \mathrm{L}$ of guanosine in flask batch culture, which constituted a 4.0 and 4.4-fold increase over the guanosine produced by the control strain BSF1G2 (Fig. 4a). Additionally, the guanosine yields of BSK756G2 and BSK814G2 were also 4.0-4.4fold higher than the yield of the strain BSF1G2 (Fig. 4b).

\section{Engineering genome-reduced strains as chassis} for thymidine production

For thymidine production, the strain BSK756 and the parental strain BSF1 were selected as the chassis strains, and the genetic modification strategy was conducted as shown in Fig. 5. We firstly knocked out the $t d k$ gene, which encodes thymidine kinase (EC 2.7.1.21), in order to avoid degradation of thymidine. This modification yielded the strains BSF1T1 and BSK756T1, respectively. Interestingly, the strain BSF1T1 did not accumulate thymidine at all, while BSK756T1 produced $24.5 \mathrm{mg} / \mathrm{L}$ of thymidine in flask batch culture (Fig. 6a). In E. coli, disruption of all three of the genes $d e o A, t d k$ and $u d p$, which are involved in the thymidine salvage pathway, could completely abolish product degradation, and even this triple knockout resulted in the production of only a small amount of thymidine [44]. However, in B. subtilis, we only found gene $t d k$ (encodes thymidine kinase, EC 2.7.1.21) and $p d p$ (encodes a pyrimidine-nucleoside phosphorylase, EC 2.4.2.2), which appear to share equivalent functions. Gene $p d p$ shares similar functions to both $\operatorname{deo} A$ (thymidine phosphorylase, EC 2.4.2.2) and $u d p$ (uridine phosphorylase, EC 2.4.2.3) of E. coli. No gene in $B$. subtilis was annotated to encode uridine phosphorylase, which would be the equivalent of $u d p$ in E. coli. What's more, gene $p d p$ was deleted in BSK756 as part of the $p d p$-rocR region (Additional file 1: Table S1), and this might be the real reason why thymidine could be accumulated by BSK756T1 but not by BSF1T1. Next, we overexpressed the gene prs in BSF1T1 and BSK756T1 from the chromosome, by inserting a $\mathrm{P}_{43}$ promoter and

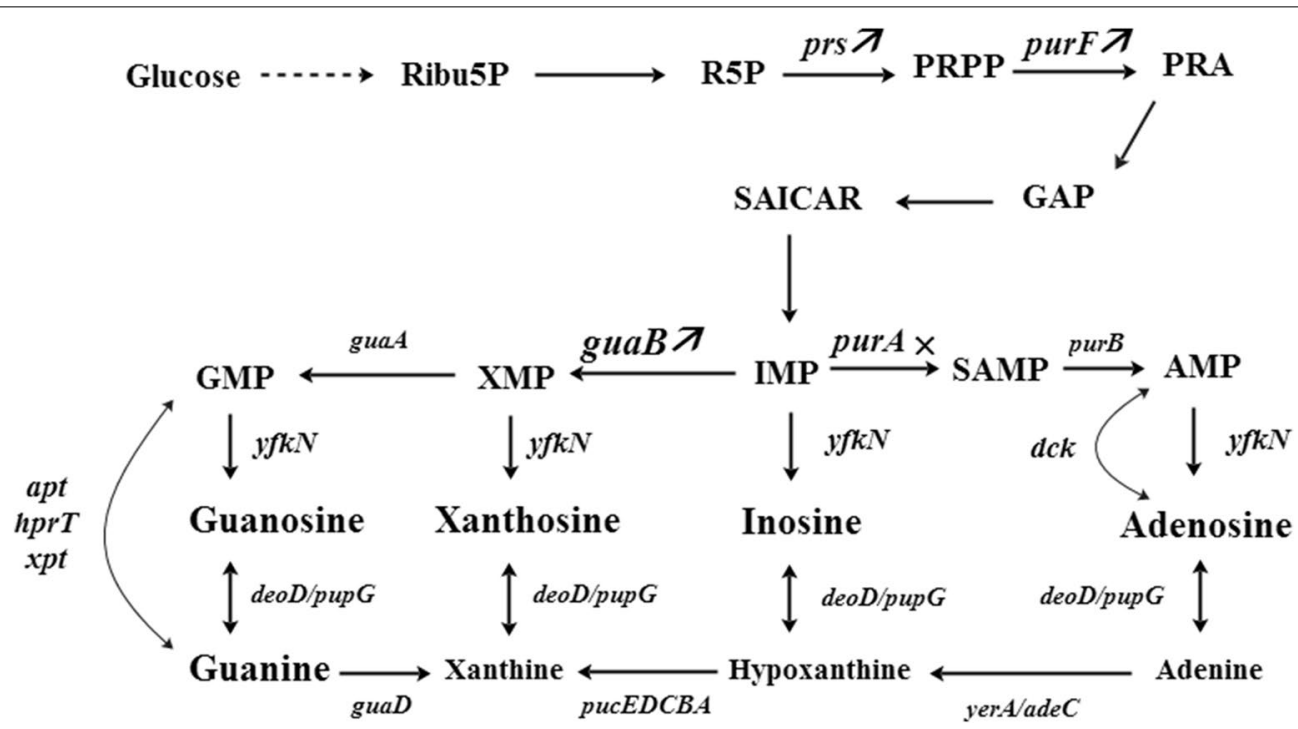

Fig. 3 Engineering strategy for guanosine production. A deletion of the gene purA was combined with overexpression of the genes prs, purF, and guaB under the control of the strong $\mathrm{P}_{43}$ promoter. The gene abbreviations are as follows: purA encodes adenylosuccinate synthase; prs encodes ribose-phosphate pyrophosphokinase; purF encodes amidophosphoribosyltransferase; guaB encodes IMP dehydrogenase 

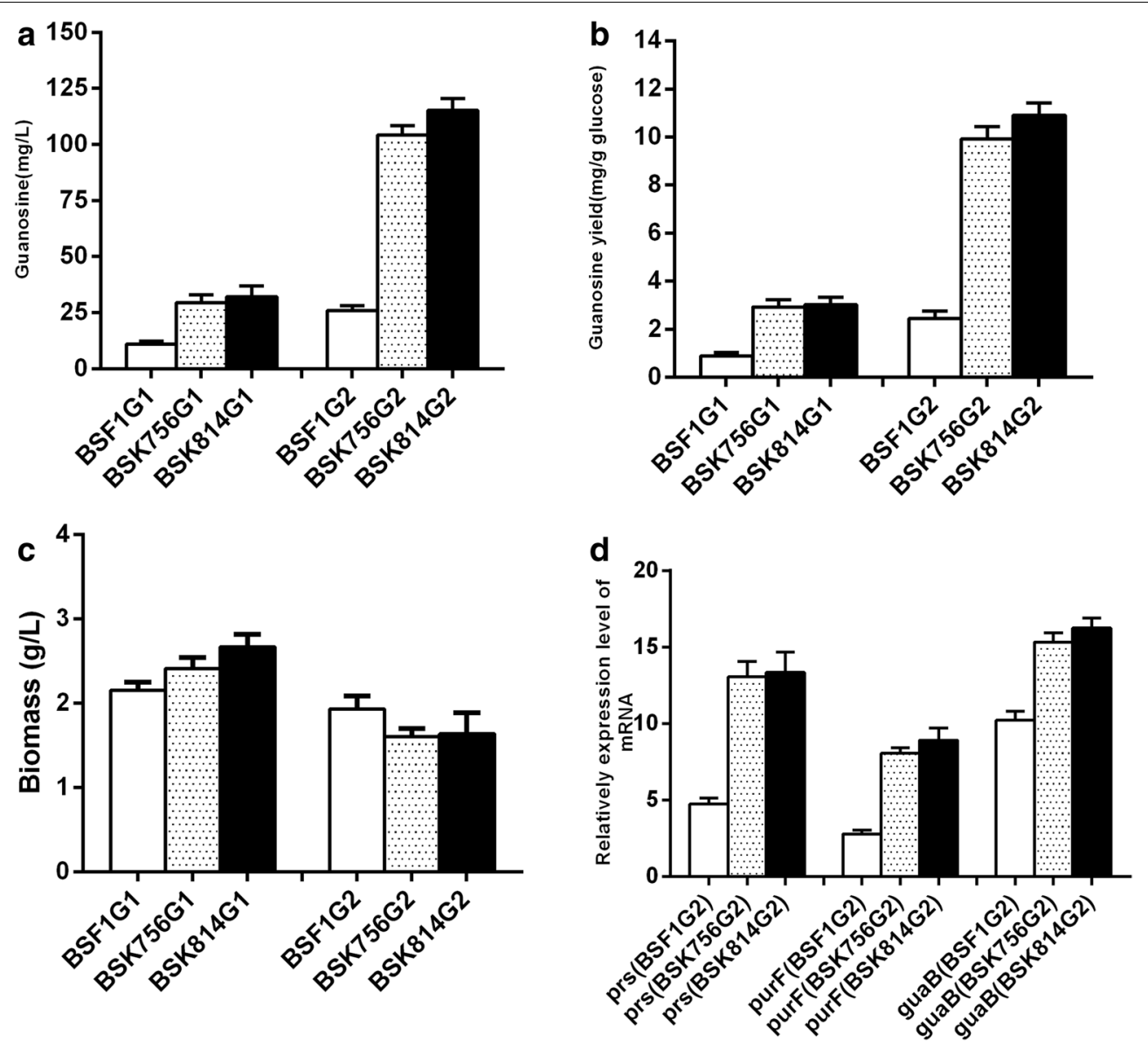

Fig. 4 Relevant indicators of guanosine production by engineered B. subtilis strains. a Guanosine production. b Guanosine yield. c Biomass. d Transcriptional expression levels of relevant genes in strains BSK756G2, BSK814G2 and BSF1G2. The strains were cultivated in 100 ml LBG medium at $37^{\circ} \mathrm{C}$ under constant orbital shaking at $220 \mathrm{rpm}$. Biomass yields were measured at $28 \mathrm{~h}$

prs gene $\left(\mathrm{P}_{43}\right.$-prs $)$ at the $b d h A$ locus in the genome. This modification yielded the strains BSF1T2 and BSK756T2, respectively. The latter strain produced $60.3 \mathrm{mg} / \mathrm{L}$ thymidine, which is approximately 2.5 -fold more than the production of the former. Finally, the two strains were further transformed with plasmid pHP13-untd, in which the ush $A$, thyA, dut and $n d k$ genes from $E$. coli were overexpressed under the control of the strong $\mathrm{P}_{43}$ promoter, which yielded the strains BSF1T3 and BSK756T3. In shake-flask cultivation, the thymidine production by BSK756T3 further increased to $151.2 \mathrm{mg} / \mathrm{L}$, which was 5.2-fold higher than that of BSF1T3 (Fig. 6a), whereas the thymidine yield of BSK756T3 increased 5.0-fold compared to BSF1T3 (Fig. 6b).

\section{Changes in expression levels of genes involved in guanosine and thymidine production}

When genome-reduced strains BSK756 and BSK814 were used as chassis cells for guanosine and thymidine production, all the derived engineered strains exhibited much higher productivities and yields than the corresponding control strains. One explanation for this result may be that the genome-reduced strains grew to a higher cell density. The biomass values of BSK756G1 and BSK814G1 were respectively 12.2 and $12.4 \%$ higher than those of the control strain BSF1G1 (Fig. 4c). Similarly, thymidine-producing strains with genome reductions also showed increased biomass values to different extents, compared to the control strains (Fig. 6c). However, we observed an opposite phenomenon for strains BSK756G2 and BSK814G2, which did not support this tentative explanation.

The second possible reason may be that the deletion of unnecessary regions from the genome could lead to more efficient cellular metabolism. Lee et al. reported that most of the genes involved in central metabolism as well as L-threonine biosynthesis were up-regulated in the genome reduced E.coli MDS-205 [10]. A different line of research by Manabe et al. indicated that the transcriptional level of the gene egl-237, which encodes an 


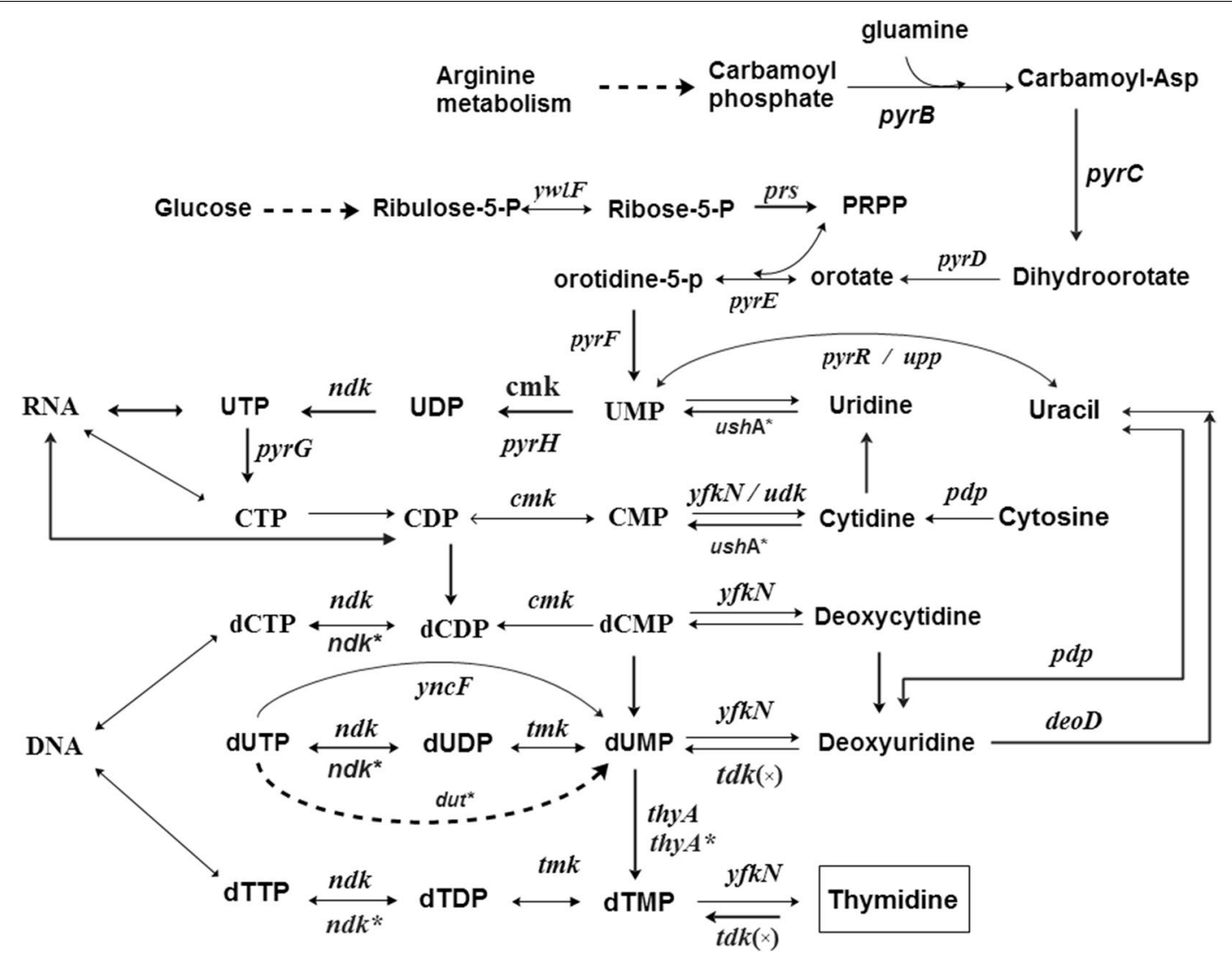

Fig. 5 Engineering strategy for thymidine production. The gene $t d k$ was deleted, and the gene prs was overexpressed by integrating a strong promoter via single crossover recombination; The genes ushA, thy A, dut, and ndk from E. coli were overexpressed from a plasmid under the control of the strong P43 promoter. The gene abbreviations are as follows: tdk encodes thymidine kinase; ushA encodes 5'-nucleotidase/UDP-sugar diphosphatase; thyA encodes thymidylate synthase; dut encodes dUTP pyrophosphatase; ndk encodes nucleoside-diphosphate kinase

extracellular alkaline cellulase, was significantly higher in strain MGB874 than in wild type 168, which directly resulted in a higher specific enzyme productivity in the genome-reduced strain [22]. To verify this, we measured the transcriptional levels of all the overexpressed genes related to guanosine and thymidine production. As shown in Fig. 4d, the transcriptional levels of the prs, purF and guaB genes in the two genome-reduced strains BSK756G2 and BSK814G2 were almost identical, but were respectively 2.7, 2.9 and 1.5-fold higher than those in BSF1G2. For genes prs, ushA, thyA, dut and $n d k$, the transcription levels in BSK756T3 were respectively 1.36, 1.92 1.81, 1.67 and 1.74-fold higher compared with those in BSF1T3 (Fig. 6d). Therefore, our results also indicated that genome-reduced strains might have a more efficient overall cellular metabolism, which might indirectly increase transcription efficiency. In addition, the four genes $u s h A$, thy $A$, dut and $n d k$ on the plasmid pHP13-untd showed a markedly higher degree of increase in their respective transcription levels than the prs gene, which was integrated into the chromosome. This could be the result of the increased copy numbers of plasmids propagated in genome-reduced strains, which is a peculiar phenomenon demonstrated earlier by Manabe et al. [22]. Ultimately, this observation might be caused mainly by the lower substrate maintenance coefficients caused by genome reduction, which allows the strains to spend more ATP on plasmid replication, in addition to increased product biosynthesis and cell growth.

Finally, since the need for direct precursors and building blocks of nucleic acids decreases directly due to large-scale genome reduction, this type of genetic manipulation makes it easier for the chassis cells to accumulate these building blocks. From this point of view, we also expect the genome-reduced strains constructed as part of this work to show greatly improved characteristics over the wild-type strain for production of other nucleosides and derived chemicals, and this is an aspect which will be further explored in our future research. 

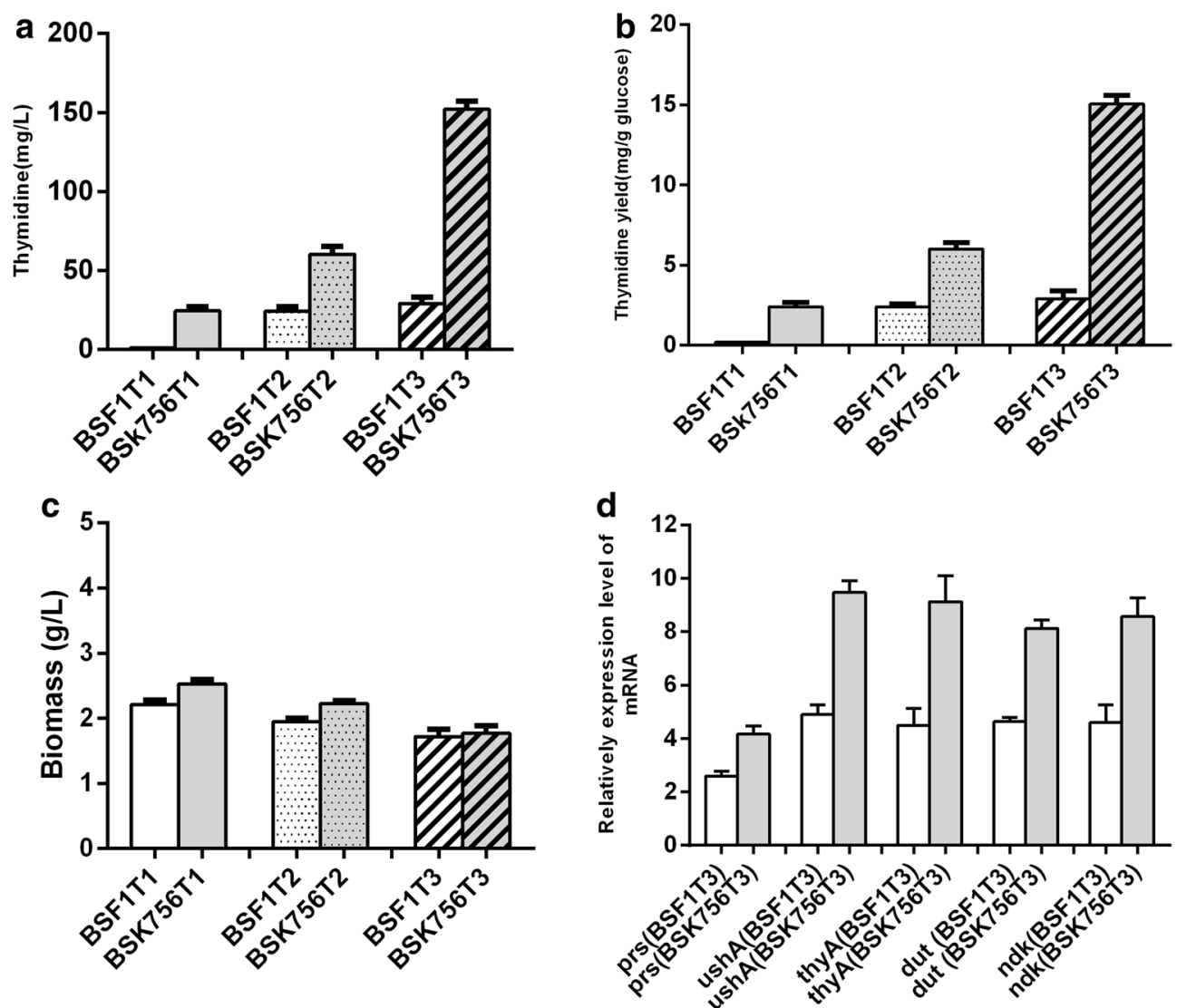

Fig. 6 Relevant indicators of thymidine production by engineered B. subtilis strains. a Thymidine production. b Thymidine yield. c Biomass $\mathbf{d}$ Transcriptional expression levels of relevant genes in the strains BSK756T3 and BSF1T3. The strains were cultivated in $100 \mathrm{ml} L B G$ medium at $37^{\circ} \mathrm{C}$ under constant orbital shaking at $220 \mathrm{rpm}$. Biomass yields were measured after $30 \mathrm{~h}$

\section{Conclusions}

In the present study, nonessential regions in the genome of $B$. subtilis 168 were deleted stepwise, whereby the maximum size of genome reduction reached $814.4 \mathrm{~kb}$. Four strains with respective genome deletion sizes of $581.9,665.2,756.8$ and $814.4 \mathrm{~kb}$ were selected to investigate the effects of genome reduction on the strains' characteristics. The specific glucose utilization and growth rates, sporulation ratios, transformation efficiencies and maintenance coefficients gradually decreased along with increasing sizes of genome reduction. On the other hand, the cell yields exhibited an opposite trend. We further constructed guanosine and thymidine producing strains by using the genome reduced strains BSK756 and/or BSK814 as chassis cells. In flask cultivation, the guanosine-producing strain BSK814G2 and thymidineproducing strain BSK756T3 accumulated $115.2 \mathrm{mg} / \mathrm{L}$ of guanosine and $151.2 \mathrm{mg} / \mathrm{L}$ thymidine, which represented a 4.4 and 5.2-fold increase compared to full-genome control strains, respectively. Although the product yields are relatively low and additional genetic modifications are needed to further improve the strains, the results presented here clearly demonstrate that strains with large-scale genome reduction possess greatly improved characteristics as chassis cells for the production of nucleoside products.

\section{Methods}

Strains, plasmids and media

All strains and plasmids used in this study are summarized in Tables 2 and 3. The strain BSF1 (B. subtilis 168 $\Delta$ upp::neo) was selected as the parental strain for genome reduction. Escherichia coli DH5 $\alpha$ was used for construction and propagation of plasmids. Escherichia coli and $B$. subtilis cells were cultured at $37^{\circ} \mathrm{C}$ in LB medium supplemented with appropriate antibiotics. Mutant selection was conducted in $\mathrm{MM}$ medium containing $2.0 \mathrm{~g} / \mathrm{L}$ $\left(\mathrm{NH}_{4}\right)_{2} \mathrm{SO}_{4} 6.0 \mathrm{~g} / \mathrm{L} \mathrm{KH_{2 }} \mathrm{PO}_{4}, 14.0 \mathrm{~g} / \mathrm{L} \mathrm{K}_{2} \mathrm{HPO}_{4}, 1.2 \mathrm{~g} / \mathrm{L}$ sodium citrate tribasic dihydrate $\left(\mathrm{Na}_{3} \mathrm{C}_{6} \mathrm{H}_{5} \mathrm{O}_{7} \cdot 2 \mathrm{H}_{2} \mathrm{O}\right)$, $0.2 \mathrm{~g} / \mathrm{L} \mathrm{MgSO}_{4} .7 \mathrm{H}_{2} \mathrm{O}, 8.0 \mathrm{~g} / \mathrm{L}$ glucose, $50 \mathrm{mg} / \mathrm{L}$ tryptophan, $2 \mathrm{~g} / \mathrm{L}$ glutamine, $10 \mu \mathrm{mol} / \mathrm{L} 5$-fluorouracil (5FU), and trace element solution as published previously [45]. 
Table 2 Strains used in this study

\begin{tabular}{|c|c|c|}
\hline Strain & Genotype & Source \\
\hline E. coli DH5a & Cloning host & Invitrogen \\
\hline BSF1 & B.subtilis 168Аupp::neo & {$[28]$} \\
\hline BSK582 & $\begin{array}{l}\text { BSF1 } \triangle \text { pro1 } \Delta \text { pro2 } \Delta \text { pro3 } \triangle \text { pro } 5 \Delta \text { pro6 } \triangle \operatorname{sp} \beta \Delta \text { pps } \Delta p k s \Delta(y c x B \text {-sip } U) \\
\quad \Delta(y i s B \text {-yit } D) \Delta(p d p-r o c R), 581.9 \text { kb reduction of genome }\end{array}$ & This study \\
\hline BSK665 & BSK582 $\triangle S p \beta^{\prime} \triangle$ skin $\triangle(y y b P-y y a), 665.2 \mathrm{~kb}$ reduction of genome & This study \\
\hline BSK756 & BSK665 $\triangle \mathrm{PBSX} \triangle(y d e K-y d j C), 756.8 \mathrm{~kb}$ reduction of genome & This study \\
\hline BSK814 & BSK756 $\triangle$ pro4 $\triangle($ lytH -yurT) $\triangle($ sboA-ywhH $), 814.4$ kb reduction of genome & This study \\
\hline BSF1T1 & BSF1 $\Delta t d k$ & This study \\
\hline BSF1T2 & BSF1 $\Delta t d k \Delta b d h A_{::} P_{43}-p r s$ & This study \\
\hline BSF1T3 & BSF1 $\Delta t d k \Delta b d h A:: \mathrm{P}_{43}$-prs, containing pHP13-untd & This study \\
\hline BSK756T1 & $\mathrm{BSK} 756 \Delta t d k$ & This study \\
\hline BSK756T2 & $\mathrm{BSK} 756 \Delta t d k \Delta b d h A_{.:} \mathrm{P}_{43}$-prs & This study \\
\hline BSK756T3 & BSK756 $\Delta t d k \Delta b d h A:: \mathrm{P}_{43}$-prs, containing pHP13-untd & This study \\
\hline BSF1G1 & BSF1 $\triangle p u r A$ & This study \\
\hline BSF1G2 & BSF1 $\triangle$ purA, containing pHP13-ppg & This study \\
\hline BSK756G1 & BSK756 $\triangle p$ purA & This study \\
\hline BSK756G2 & BSK756 $\triangle$ purA, containing pHP13-ppg & This study \\
\hline BSK814G1 & BSK814 $\triangle p u r A$ & This study \\
\hline BSK814G2 & BSK814 $\triangle$ purA, containing pHP13-ppg & This study \\
\hline
\end{tabular}

M9 medium, supplemented with $1 \%(\mathrm{w} / \mathrm{v})$ glucose, $100 \mathrm{mM}$ MOPS and $50 \mathrm{mg} / \mathrm{L}$ tryptophan, was used for assessing growth of genome-reduced strains [46]. SM1 and SM2 media were used for the preparation of $B$. subtilis competent cells as described previously [38]. Glucose-limited medium for continuous culture contained components as reported by Sauer et al. [40]. LBG medium for guanosine and thymidine production contained $10 \mathrm{~g} / \mathrm{L}$ tryptone, $5 \mathrm{~g} / \mathrm{L}$ yeast extract, $10 \mathrm{~g} / \mathrm{L}$ sodium chloride, $10 \mathrm{~g} / \mathrm{L}$ water-free glucose and $0.1 \mathrm{~mol} / \mathrm{L}$ MOPS. Where appropriate, $5 \mu \mathrm{g} / \mathrm{ml}$ chloramphenicol $(\mathrm{Cm}), 10 \mu \mathrm{g} / \mathrm{ml}$ kanamycin $(\mathrm{Km})$ or $5 \mu \mathrm{g} / \mathrm{ml}$ erythromycin $(\mathrm{Em})$ was added to promote plasmid retention. Unless otherwise specified, the reagents and antibiotics used in this study were purchased from Sangon biotech Co., Ltd (Shanghai, China) and were of the highest available purity.

\section{Plasmid construction}

The plasmids $\mathrm{pU}$ and $\mathrm{pCU}$ were used as backbones to construct targeting plasmids for genome streamlining. Upstream and downstream sequences of the target region or gene were amplified using PCR and assembled using splicing by overlap extension PCR (SOE-PCR), and cloned into the multiple cloning sites (MCS) of the backbone plasmids, yielding the plasmids pCU-tdk and pCU-purA. To improve the efficiency of large-scale deletions, a subset of the plasmids was constructed using the following method: the upstream sequence, downstream sequences of the target region as well as an internal sequence in the target region were amplified by PCR. The upstream sequence and the downstream sequence of the target region were fused by SOE-PCR, the resulting fragment was digested and ligated into the MCS-I site of plasmid pU. The internal sequence was cloned into the MCS-II site of plasmid pU. The derived plasmid, containing upstream sequence, internal sequence, cat-upp cassette, and downstream sequence, was linearized and used for deletions of large regions. For plasmid pHP13ppg, the genes prs, purF and guaB were amplified from the genome of $B$. subtilis 168 , the corresponding DNA fragments digested and ligated step by step into the plasmid pHP13, finally yielding the plasmid pHP13-ppg in which the genes prs, purF and guaB were overexpressed under the control of the strong $\mathrm{P}_{43}$ promoter. The plasmid pHP13-untd was constructed in the same way as described above. The genes $u s h A$, thy $A, d u t$ and $n d k$ were amplified from E. coli MG1655 genomic DNA by PCR. These corresponding DNA fragments were digested and ligated into the plasmid pHP13 step by step, generating plasmid pHP13-untd in which the transcription of all four genes was controlled by the strong $\mathrm{P}_{43}$ promoter. The plasmid pCU-bdhA-prs was constructed as reported previously [47].

\section{Genetic manipulation for genome reduction}

To facilitate successive deletion procedures, we adopted a scarless deletion method using $u p p$ as counterselection 
marker (Additional file 1: Figure S4) [48]. A linearized targeting plasmid, containing homologous fragments flanking the counterselection cassette, was used to transform competent cells of the recipient strain. Positive transformants were selected on plates containing chloramphenicol and transferred into LB liquid medium. After cultivation for either 6 or $12 \mathrm{~h}$, appropriate amounts of cells were spread onto MM agar plates. Colonies that grew on MM agar plates were further verified by PCR.

\section{Physiological analyses}

Growth characterization of deletion mutants was performed by streaking the strains on LB agar plates from $-80{ }^{\circ} \mathrm{C}$ glycerol stocks and cultivating at $37{ }^{\circ} \mathrm{C}$, transferring single colonies from the plates into $50 \mathrm{ml} \mathrm{M} 9$ medium and culturing overnight at $37{ }^{\circ} \mathrm{C}$ under constant orbital shaking at $220 \mathrm{rpm}$. Subsequently $2 \mathrm{ml}$ culture aliquots were used to inoculate $500 \mathrm{ml}$ shake flasks containing $100 \mathrm{ml} \mathrm{M} 9$ medium and the cells further cultivated at $37^{\circ} \mathrm{C}$ and $240 \mathrm{rpm}$. All experiments were performed in triplicate.

The cell lysis assay was performed using sodium azide as described previously [33]. Sodium azide is a cytochrome oxidase inhibitor and can lead to disruption of cell division. It is often used to monitor dynamic process of autolysis in real time. Briefly, the cells were grown in LB medium until mid-exponential phase, after which a final concentration of $0.05 \mathrm{M}$ sodium azide was added to the culture medium and incubation continued at $37{ }^{\circ} \mathrm{C}$ and $220 \mathrm{rpm}$. The optical density $\left(\mathrm{OD}_{600}\right)$ of the cultures was monitored periodically. Cell lysis was calculated by comparing the ratio of $\mathrm{OD}_{600}$ at each sampling timepoint to the initial $\mathrm{OD}_{600}$.

To study spore formation of mutants, cells were incubated in Difco sporulation medium (DSM) and shaken at $37{ }^{\circ} \mathrm{C}$ for $24 \mathrm{~h}$ to induce sporulation. One millilitre aliquots of the DSM cultures were heated at $80{ }^{\circ} \mathrm{C}$ for $20 \mathrm{~min}$ to kill vegetative cells. Heated and unheated aliquots were diluted and plated on LB-agar plates. After incubation at $37{ }^{\circ} \mathrm{C}$ for $72 \mathrm{~h}$, the ratio of the number of colonies from corresponding heated and unprocessed aliquots was used to calculate sporulation rates. All experiments were performed in triplicate.

Transformation efficiency was determined according to the method described by Vojcic et al. [38], with minor modifications. Briefly, fresh single colonies were inoculated into flasks containing SM1 medium. The resulting overnight cultures were then diluted with SM1 medium, the optical density at $600 \mathrm{~nm}$ adjusted to 0.3 in a volume

Table 3 plasmids used in this study

\begin{tabular}{|c|c|c|}
\hline plasmid & Genotype & Source \\
\hline $\mathrm{pU}$ & pUC18, Amp ${ }^{R}$, containing cat-upp and two MCS regions & Lab stock \\
\hline $\mathrm{pCU}$ & pUC18, Amp ${ }^{R}$, containing cat-upp and a MCS region & Lab stock \\
\hline pU-pro1 & $\mathrm{pU}$, containing pro1 upstream, downstream flanks and an internal fragment in target region & This study \\
\hline pU-pro2 & $\mathrm{pU}$, containing pro2 upstream, downstream flanks and an internal fragment in target region & This study \\
\hline pCU-pro3 & $\mathrm{pCU}$, containing pro3 upstream and downstream flanks & This study \\
\hline pU-pro4 & $\mathrm{pU}$, containing pro4 upstream, downstream flanks and an internal fragment in target region & This study \\
\hline pU-pro5 & $\mathrm{pU}$, containing pro5 upstream, downstream flanks and an internal fragment in target region & This study \\
\hline pU-pro6 & $\mathrm{pU}$, containing pro6 upstream, downstream flanks and an internal fragment in target region & This study \\
\hline pU-PBSX & $\mathrm{pU}$, containing upstream, downstream flanks of PBSX and an internal fragment in target region & This study \\
\hline pU-skin & $\mathrm{pU}$, containing upstream, downstream flanks of skin and an internal fragment in target region & This study \\
\hline $\mathrm{pU}-\mathrm{sp} \beta$ & $\mathrm{pU}$, containing upstream, downstream flanks of $\mathrm{sp} \beta$ and an internal fragment in target region & This study \\
\hline $\mathrm{pU}-\mathrm{sp} \beta^{\prime}$ & $\mathrm{pU}$, containing upstream, downstream flanks of target region and an internal fragment in target region & This study \\
\hline pU-yrkS-yraK & $\mathrm{pU}$, containing upstream, downstream flanks of target and an internal fragment in target region & This study \\
\hline pU-yisB-yitD & $\mathrm{pU}$, containing upstream, downstream flanks of target and an internal fragment in target region & This study \\
\hline pU-ycxB-sipU & $\mathrm{pU}$, containing upstream, downstream flanks of target and an internal fragment in target region & This study \\
\hline pU-pdp-rocR & $\mathrm{pU}$, containing upstream, downstream flanks of target and an internal fragment in target region & This study \\
\hline pCU-tdk & $\mathrm{Amp}^{\mathrm{R}}, \mathrm{Cm}^{\mathrm{R}}$, containing $t d k$ upstream and downstream flanks of target region & This study \\
\hline pCU-purA & $\mathrm{Amp}^{R}, \mathrm{Cm}^{\mathrm{R}}$, containing purA upstream and downstream flanks & This study \\
\hline pCU-bdhA-prs & $\mathrm{Amp}^{\mathrm{R}}, \mathrm{Cm}^{\mathrm{R}}$, containing $b d h A$ upstream and downstream flanks, $\mathrm{P}_{43}$-prs & This study \\
\hline pHP13 & $\mathrm{Cm}^{\mathrm{R}}, \mathrm{Em}^{\mathrm{R}}$, B.subtils-E. coli shuttle plasmid & Lab stock \\
\hline pHP13-ppg & pHP13 replication, $\mathrm{Cm}^{\mathrm{R}}, \mathrm{Em}^{\mathrm{R}}, \mathrm{P}_{43}$-prs-purF-guaB & This study \\
\hline pHP13-untd & pHP13 replication, $\mathrm{Cm}^{\mathrm{R}}, \mathrm{Em}^{\mathrm{R}}, \mathrm{P}_{43}$-ushA-ndk-thyA-dut & This study \\
\hline
\end{tabular}

$\mathrm{Amp}^{\mathrm{R}}$, ampicillin resistance; $\mathrm{Cm}^{\mathrm{R}}$, chloramphenicol resistance; $\mathrm{Em}^{\mathrm{R}}$, erythromycin resistance 
of $10 \mathrm{ml}$ and incubated at $37{ }^{\circ} \mathrm{C}$ and $220 \mathrm{rpm}$. When the cells exited the exponential growth phase, the cultures were transferred to $5 \mathrm{ml} \mathrm{SM} 2$ medium at a ratio of 1:1, and incubated until the cells reached the late exponential growth phase. The competent cells were contacted with 100 ng of pHP13 plasmid DNA. After incubation for $1 \mathrm{~h}$, the cells were plated on selective medium plates and the numbers of the resulting colonies were used to calculate transformation efficiency values of the mutant strains.

To determine the maintenance coefficients of the strains, continuous cultivations of each strain were conducted in a 1.5-L Fermenter (BioFlo 110, New Brunswick Scientific Co. Inc.,USA) containing $0.4 \mathrm{~L}$ of glucoselimited medium. Seed cultures grown at $37^{\circ} \mathrm{C}$ in $250 \mathrm{ml}$ flasks containing $50 \mathrm{ml}$ of seed medium were used to inoculate the fermenter. When glucose was nearly exhausted, the cultivation was switched from batch to chemostat mode. The fermentation volume was kept constant using an automated pump. The $\mathrm{pH}$ of the culture medium was maintained at 6.65 with $0.1 \mathrm{~mol} / \mathrm{L}$ $\mathrm{NaOH}$. Aeration rate, agitation speed and temperature were controlled at $0.2 \mathrm{vvm}, 400 \mathrm{rpm}$ and $37^{\circ} \mathrm{C}$, respectively. The dilution rate (D) was increased stepwise from 0.1 to $0.5 \mathrm{~h}^{-1}$. Each $\mathrm{D}$ value was determined by feeding medium at a predesigned flow rate. Cell growth subsequently reached a steady state at which cell density and glucose consumption rate remained unchanged for prolonged periods of time. Samples were collected and weighed after drying at $80{ }^{\circ} \mathrm{C}$ to constant weight, and glucose consumption was constantly monitored at the same time. Experimental values for the maintenance coefficient which were expressed as glucose consumption rate $\left(\mathrm{m}_{\mathrm{glc}}\right)$ were derived from fitted linear regression lines.

Engineering guanosine and thymidine synthesis pathways The strains BSK756 and BSK814 were selected for guanosine biosynthesis engineering. Plasmid pCU-purA was used to delete purA gene in the strains BSF1, BSK756 and BSK814, yielding the strains BSF1G1, BSK756G1 and BSK814G1, respectively. Subsequently, the plasmid pHP13-ppg was introduced into the purA-deficient mutants to overexpress genes prs, purF and guaB, resulting in strains BSF1G2, BSK756G2 and BSK814G2, respectively.

For thymidine production, $t d k$ gene was deleted, and genes prs, ushA, thy $A$, dut and $n d k$ were overexpressed. Firstly, $t d k$ was knocked out using the plasmid pCU-tdk as described previously, resulting in strains BSF1T1 and BSK756T1. Subsequently, the plasmid pCU-bdhA-prs was introduced and integrated into the chromosome of the recipient cells by a first single-crossover event, and a second single-crossover event during $12 \mathrm{~h}$ cultivation in LB liquid medium yielded the mutant strains BSF1T2 and
BSK756T2, in which $b d h A$ has been replaced by the $\mathrm{P}_{43}$ prs fragment. Genes $u s h A$, thy $A$, dut and $n d k$ were overexpressed by introducing the plasmid pHP13-untd into BSF1T2 and BSK756T2, yielding BSF1T3 and BSK756T3, respectively. For fermentations, single colonies of $B$. subtilis were transferred into $5 \mathrm{ml} \mathrm{LB}$ medium and incubated at $37{ }^{\circ} \mathrm{C}$ and $220 \mathrm{rpm}$. The resulting overnight cultures were used to inoculate $500-\mathrm{ml}$ shake flasks containing $100 \mathrm{ml} \mathrm{LBG}$ medium and cultivated at $37^{\circ} \mathrm{C}$ and $220 \mathrm{rpm}$.

\section{Analytical methods}

The shape and size of cell were examined and recorded using an Olympus CX41 microscope equipped with an digital camera (Olympus, Tokyo, Japan). All photomicrographs were taken at $1000 \times$ magnification. Cell growth was monitored by measuring the optical density at $600 \mathrm{~nm}\left(\mathrm{OD}_{600}\right)$ using a UV-Vis spectrophotometer(TU-1801, Beijing PuxiUniversal Co., Ltd., Beijing, China). Glucose consumption was quantified using a biosensor (SBA-40C, Biology Institute of Shandong Academy of Science, Shandong, China) [49]. Analysis of thymidine and guanosine concentrations was performed using reverse-phase HPLC (HP1100, Agilent, USA) equipped with a Luna C18 column (2) $(150 \times 4.6 \mathrm{~mm}, 5 \mu \mathrm{m}$, Phenomenex, USA $)$ and the eluents were followed photometrically at $260 \mathrm{~nm}$. For thymidine, the mobile phase was $4 \%(\mathrm{v} / \mathrm{v})$ acetonitrile/water containing $0.05 \%(\mathrm{v} / \mathrm{v})$ trifluoroacetic acid; The flow rate was $1 \mathrm{ml} / \mathrm{min}$; The retention time for thymidine was $7.35 \mathrm{~min}$ [50]. For guanosine, the mobile phase was $4 \%$ (v/v) acetonitrile/water; The flow rate was $0.6 \mathrm{ml} / \mathrm{min}$; The retention time for guanosine was $13.21 \mathrm{~min}$.

Quantitative real-time reverse transcription PCR analysis was performed as follows: cultures were harvested when cells reached the mid-exponential growth phase. RNA was extracted using the RNAprep pure Cell/Bacteria Kit (Tiangen, Beijing, China) according to the manufacturer's protocol. Subsequently the RNA was used as template to amplify cDNA using the FastQuant RT Kit (Tiangen, Beijing, China). The resulting cDNA was analysed using a Light Cycler 480 II (Roche, Basel, Switzerland) and RealMasterMix (SYBR Green I, Tiangen, Beijing, China). The 16s rRNA gene rrnA-16S was used as internal control. Data were quantified using the $2^{-\Delta \Delta C t}$ method.

\section{Additional file}

Additional file1: Figure S1. Strategy for the construction of genome reduced strains of B.subtilis; Figure S2. Growth and glucose consumption of genome-reduced strains and the parental strain BSF1 in M9 medium; Figure S3. Cell morphology of genome-reduced strains and their parental strain BSF1; Figure S4. Schematic representation of the scarless deletion methods for genome streamlining; Table S1. Regions deleted in the course of genome reduction; Table S2. Primers used in this study. 


\section{Abbreviations}

5FU: 5-fluorouracil; Cm: chloramphenicol; Km: kanamycin; Em: erythromycin; DSM: difco sporulation medium; cdw: cell dry weigh; D: dilution rate.

\section{Authors' contributions}

$Y L$ and TC designed the experiments; $Y L, X Z, X Z$, JF and WZW performed the experiments; $Y L$ and TC wrote the manuscript; TC and XMZ supervised the work; All authors contributed to the discussion of the research. All authors read and approved the final manuscript.

\section{Author details \\ ${ }^{1}$ Key Laboratory of Systems Bioengineering (Ministry of Education), SynBio Research Platform, Collaborative Innovation Center of Chemical Science and Engineering (Tianjin), School of Chemical Engineering and Technol- ogy, Tianjin University, Tianjin 300072, China. ${ }^{2}$ Hubei Provincial Cooperative Innovation Center of Industrial Fermentation, Key Laboratory of Fermenta- tion Engineering (Ministry of Education), Hubei University of Technology, Wuhan 430068, China. ${ }^{3}$ Tianjin Vocational College of Bioengineering, Tian- jin 300462, China. ${ }^{4}$ College of Life Science, Shihezi University, Shihezi 832000 China.}

\section{Acknowledgements}

We thank the anonymous reviewers and the editor for their comments. This work was supported by the National Natural Science Foundation of China (NSFC-21176182, 21576200, 21576191), and National Program on Key Basic Research Project (2012CB725203).

\section{Competing interests}

All authors declare that they have no competing interests.

\section{Consent for publication}

Not applicable.

\section{Ethics approval and consent to participate}

Not applicable.

\section{Funding}

The design of the study and experiment materials were supported by National Natural Science Foundation of China NSFC-21176182, 21576200, 21576191), Data analysis and interpretation, and manuscript preparation were supported by National Program on Key Basic Research Project (2012CB725203).

Received: 1 February 2016 Accepted: 23 May 2016

Published online: 03 June 2016

\section{References}

1. Foley PL, Shuler ML. Considerations for the design and construction of a synthetic platform cell for biotechnological applications. Biotechnol Bioeng. 2010;105:26-36.

2. Leprince A, van Passel MW, dos Santos VA. Streamlining genomes: toward the generation of simplified and stabilized microbial systems. Curr Opin Biotechnol. 2012;23:651-8.

3. Ochman H. Genomes on the shrink. Proc Natl Acad Sci USA. 2005;102:11959-60.

4. Koonin EV. How many genes can make a cell: minimal gene set concept. Annu Rev Genomics Hum Genet. 2000;1(1):99-116.

5. Rocha EP. The organization of the bacterial genome. Annu Rev Genet. 2008;42:211-33.

6. Mira A, Klasson L, Andersson SG. Microbial genome evolution: sources of variability. Curr Opin Microbiol. 2002;5:506-12.

7. Gao H, Zhuo Y, Ashforth E, Zhang L. Engineering of a genome-reduced host: practical application of synthetic biology in the overproduction of desired secondary metabolites. Protein Cell. 2010;1:621-6.

8. Komatsu M, Uchiyama T, Omura S, Cane DE, Ikeda H. Genome-minimized Streptomyces host for the heterologous expression of secondary metabolism. Proc Natl Acad Sci USA. 2010;107:2646-51.

9. Sharma SS, Blattner FR, Harcum SW. Recombinant protein production in an Escherichia coli reduced genome strain. Metab Eng. 2007;9:133-41.
10. Lee JH, Sung BH, Kim MS, Blattner FR, Yoon BH, Kim JH, Kim SC. Metabolic engineering of a reduced-genome strain of Escherichia coli for L-threonine production. Microb Cell Fact. 2009;8:2.

11. Posfai G, Plunkett III G, Feher T, Frisch D, Keil GM, Umenhoffer K, Kolisnychenko V, Stahl B, Sharma SS, de Arruda M, et al. Emergent properties of reduced-genome Escherichia coli. Science. 2006;312:1044-6.

12. Mizoguchi H, Sawano Y, Kato J, Mori H. Superpositioning of deletions promotes growth of Escherichia coli with a reduced genome. DNA Res. 2008;15:277-84.

13. Hirokawa Y, Kawano H, Tanaka-Masuda K, Nakamura N, Nakagawa A, Ito M, Mori H, Oshima T, Ogasawara N. Genetic manipulations restored the growth fitness of reduced-genome Escherichia coli. J Biosci Bioeng. 2013;116:52-8.

14. Baumgart M, Unthan S, Ruckert C, Sivalingam J, Grunberger A, Kalinowski J, Bott M, Noack S, Frunzke J. Construction of a prophage-free variant of Corynebacterium glutamicum ATCC 13032 for use as a platform strain for basic research and industrial biotechnology. Appl Environ Microbiol. 2013;79:6006-15

15. Lieder S, Nikel PI, de Lorenzo V, Takors R. Genome reduction boosts heterologous gene expression in Pseudomonas putida. Microb Cell Fact. 2015;14:23.

16. Ara K, Ozaki K, Nakamura K, Yamane K, Sekiguchi J, Ogasawara N. Bacillus minimum genome factory: effective utilization of microbial genome information. Biotechnol Appl Biochem. 2007;46:169-78.

17. Akeno Y, Ying BW, Tsuru S, Yomo T. A reduced genome decreases the host carrying capacity for foreign DNA. Microb Cell Fact. 2014;13:49.

18. Unthan S, Baumgart M, Radek A, Herbst M, Siebert D, Bruhl N, Bartsch A, Bott M, Wiechert W, Marin K, et al. Chassis organism from Corynebacterium glutamicum-a top-down approach to identify and delete irrelevant gene clusters. Biotechnol J. 2015;10:290-301.

19. Schallmey M, Singh A, Ward OP. Developments in the use of Bacillus species for industrial production. Can J Microbiol. 2004;50:1-17.

20. Westers H, Dorenbos R, van Dijl JM, Kabel J, Flanagan T, Devine KM, Jude F, Seror SJ, Beekman AC, Darmon E, et al. Genome engineering reveals large dispensable regions in Bacillus subtilis. Mol Biol Evol. 2003;20:2076-90.

21. Morimoto T, Kadoya R, Endo K, Tohata M, Sawada K, Liu S, Ozawa T, Kodama T, Kakeshita H, Kageyama Y, et al. Enhanced recombinant protein productivity by genome reduction in Bacillus subtilis. DNA Res. 2008;15:73-81.

22. Manabe K, Kageyama Y, Morimoto T, Ozawa T, Sawada K, Endo K, Tohata M, Ara K, Ozaki K, Ogasawara N. Combined effect of improved cell yield and increased specific productivity enhances recombinant enzyme production in genome-reduced Bacillus subtilis strain MGB874. Appl Environ Microbiol. 2011;77:8370-81.

23. Manabe K, Kageyama Y, Tohata M, Ara K, Ozaki K, Ogasawara N. High external pH enables more efficient secretion of alkaline alpha-amylase AmyK38 by Bacillus subtilis. Microb Cell Fact. 2012;11:74.

24. Toya Y, Hirasawa T, Morimoto T, Masuda K, Kageyama Y, Ozaki K, Ogasawara N, Shimizu H. 13 C-metabolic flux analysis in heterologous cellulase production by Bacillus subtilis genome-reduced strain. J Biotechnol. 2014:179:42-9.

25. Zhu H, Yang SM, Yuan ZM, Ban R. Metabolic and genetic factors affecting the productivity of pyrimidine nucleoside in Bacillus subtilis. Microb Cell Fact. 2015;14:54.

26. Shi S, Chen T, Zhang Z, Chen X, Zhao X. Transcriptome analysis guided metabolic engineering of Bacillus subtilis for riboflavin production. Metab Eng. 2009;11:243-52.

27. De Wulf P, Soetaert W, Schwengers D, Vandamme EJ. Optimization of D-ribose production with a transketolase-affected Bacillus subtilis mutant strain in glucose and gluconic acid-based media. J Appl Microbiol. 1997;83:25-30

28. Fu J, Wang Z, Chen T, Liu W, Shi T, Wang G, Tang YJ, Zhao X. NADH plays the vital role for chiral pure D-(-)-2,3-butanediol production in Bacillus subtilis under limited oxygen conditions. Biotechnol Bioeng. 2014;111:2126-31.

29. Zhang X, Zhang R, Bao T, Rao Z, Yang T, Xu M, Xu Z, Li H, Yang S. The rebalanced pathway significantly enhances acetoin production by disruption of acetoin reductase gene and moderate-expression of a new waterforming NADH oxidase in Bacillus subtilis. Metab Eng. 2014;23:34-41.

30. Kunst F, Ogasawara N, Moszer I, Albertini AM, Alloni G, Azevedo V, Bertero MG, Bessieres P, Bolotin A, Borchert S, et al. The complete genome 
sequence of the gram-positive bacterium Bacillus subtilis. Nature. 1997;390:249-56.

31. Smith TJ, Blackman SA, Foster SJ. Autolysins of Bacillus subtilis: multiple enzymes with multiple functions. Microbiology. 2000;146(Pt 2):249-62.

32. Smith TJ, Foster SJ. Autolysins during sporulation of Bacillus subtilis 168. FEMS Microbiol Lett. 1997;157(1):141-7.

33. Wang $Y$, Chen Z, Zhao R, Jin T, Zhang $X$, Chen $X$. Deleting multiple lytic genes enhances biomass yield and production of recombinant proteins by Bacillus subtilis. Microb Cell Fact. 2014;13:129.

34. Higgins D, Dworkin J. Recent progress in Bacillus subtilis sporulation. FEMS Microbiol Rev. 2012;36:131-48

35. Naclerio G, Baccigalupi L, Zilhao R, Felice MD, Ricca E. Bacillus subtilis spore coat assembly requires cotH gene expression. J Bacteriol. 1996; 178:4375-80.

36. Chen Y, Ray WK, Helm RF, Melville SB, Popham DL. Levels of germination proteins in Bacillus subtilis dormant, superdormant, and germinating spores. PLoS One. 2014;9:e95781.

37. Bott KF, Wilson GA. Metabolic and nutritional factors influencing the development of competence for transfection of Bacillus subtilis. Bacteriol Rev. 1968;32:370-8.

38. Vojcic L, Despotovic D, Martinez R, Maurer KH, Schwaneberg U. An efficient transformation method for Bacillus subtilis DB104. Appl Microbiol Biotechnol. 2012;94:487-93.

39. Hamoen LW. Controlling competence in Bacillus subtilis: shared use of regulators. Microbiology. 2003;149:9-17.

40. Sauer U, Hatzimanikatis V, Hohmann HP, Manneberg M, van Loon AP, Bailey JE. Physiology and metabolic fluxes of wild-type and riboflavinproducing Bacillus subtilis. Appl Environ Microbiol. 1996;62:3687-96.
41. Vickers CE, Blank LM, Kromer JO. Chassis cells for industrial biochemical production. Nat Chem Biol. 2010;6:875-7.

42. Tannler S, Decasper S, Sauer U. Maintenance metabolism and carbon fluxes in Bacillus species. Microb Cell Fact. 2008;7:19.

43. Mitsuya H, Weinhold KJ, Furman PA. St Clair MH, Lehrman SN, Gallo RC, Bolognesi D, Barry DW, Broder S: 3'-Azido-3'-deoxythymidine (BW A509U): an antiviral agent that inhibits the infectivity and cytopathic effect of human T-lymphotropic virus type III/lymphadenopathy-associated virus in vitro. Proc Natl Acad Sci U S A. 1985;82:7096-100.

44. Lee HC, Kim JH, Kim JS, Jang W, Kim SY. Fermentative production of thymidine by a metabolically engineered Escherichia coli strain. Appl Environ Microbiol. 2009;75:2423-32

45. Shi T, Wang G, Wang Z, Fu J, Chen T, Zhao X. Establishment of a markerless mutation delivery system in Bacillus subtilis stimulated by a double-strand break in the chromosome. PLoS One. 2013;8:e81370.

46. Harwood CR, Cutting SM. Molecular biological methods for Bacillus. England:Wiley; 1990.

47. Shi T, Wang Y, Wang Z, Wang G, Liu D, Fu J, Chen T, Zhao X. Deregulation of purine pathway in Bacillus subtilis and its use in riboflavin biosynthesis. Microb Cell Fact. 2014;13:101.

48. Fabret C, Ehrlich SD, Noirot P. A new mutation delivery system for genome-scale approaches in Bacillus subtilis. Mol Microbiol. 2002;46:25-36.

49. Feng D, Li M, Zhu S, Zhou W, Huang J, Feng D. Study on sucrose-glucose bifunction assay of biosensor analyzer. Food Science. 2002;23:117-21.

50. Magaña AA, Wrobel K, Caudillo YA, Zaina S, Lund G, Wrobel K. Highperformance liquid chromatography determination of 5-methyl2'-deoxycytidine, 2'-deoxycytidine, and other deoxynucleosides and nucleosides in DNA digests. Anal Biochem. 2008;374:378-85.

\section{Submit your next manuscript to BioMed Central and we will help you at every step:}

- We accept pre-submission inquiries

- Our selector tool helps you to find the most relevant journal

- We provide round the clock customer support

- Convenient online submission

- Thorough peer review

- Inclusion in PubMed and all major indexing services

- Maximum visibility for your research

Submit your manuscript at www.biomedcentral.com/submit
() Biomed Central 